\title{
An unusual cause of abdominal pain in a middle-aged man
}

\author{
Amin Abdurahman Abukar, ${ }^{1}$ Phoebe Leung, ${ }^{1}$ Paul Vulliamy, ${ }^{2}$ Timothy Cheatle ${ }^{2}$
}

${ }^{1}$ Department of General Surgery, Queen's Hospital, London, UK

${ }^{2}$ Queen's Hospital, London, UK

\section{Correspondence to}

Dr Amin Abdurahman Abukar, amin_abukar@hotmail.co.uk

Accepted 9 August 2015

\footnotetext{
To cite: Abukar AA, Leung $P$, Vulliamy $P$, et al. BMJ Case Rep Published online: [please include Day Month Year] doi:10.1136/ bcr-2015-211986
}

\section{DESCRIPTION}

A 53-year-old man with a history of hypercholesterolaemia and symptomatic cholelithiasis presented with a 1-day history of bilious vomiting, intermittent abdominal pain, anorexia and absolute constipation. Physical examination revealed a mildly distended, tense abdomen that was tender in the lower quadrants. Percussion note was tympanic and bowel sounds were absent on auscultation. An urgent $\mathrm{CT}$ of the abdomen and pelvis was requested (figure 1). CT showed evidence of mild fatty infiltration of the liver and emphysematous cholecystitis without cholelithiasis. There was also evidence of a moderate amount of pneumobilia, mildly dilated small bowel loops and a well-defined radiodense material noted in the ileum. The patient was resuscitated and underwent laparotomy and enterolithotomy, with the consequent retrieval of a large $4 \mathrm{~cm}$ gallstone (figure 2). The postoperative course was uneventful and the patient was discharged following 2 weeks of hospital stay.

The features described are characteristic of gallstone ileus, namely, Rigler's triad, which classically includes mechanical bowel obstruction, ectopic gallstone within the bowel lumen and pneumobilia. Plain abdominal radiographs usually display nonspecific findings as only a few (10\%) gallstones are sufficiently calcified to be seen radiographically. Abdominal ultrasound scan may confirm presence of gallstones and a fistula. However, abdominal CT scan is the gold standard in diagnosing gallstone ileus due to its superior resolution. Lanssandro and colleagues found that Rigler's triad was present in $11.11 \%$ of patients on abdominal ultrasound scan, $14.81 \%$ on plain abdominal radiograph and $77.78 \%$ on abdominal CT scan. Use of CT scan may result in a faster diagnosis and also aids decision-making in the surgical management. ${ }^{12}$

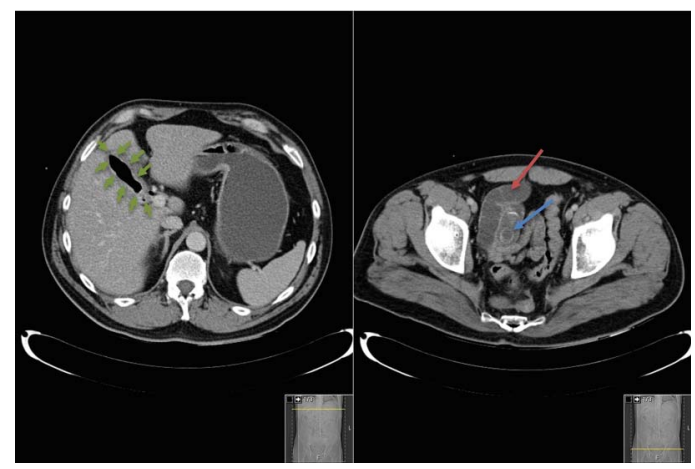

Figure 1 Axial contrast-enhanced CT of the abdomen showing air in the gallbladder and common bile duct (green arrows: pneumobilia), gallstone in the small bowel (blue arrow) and dilated loops of small bowel (red arrow) in keeping with gallstone ileus.

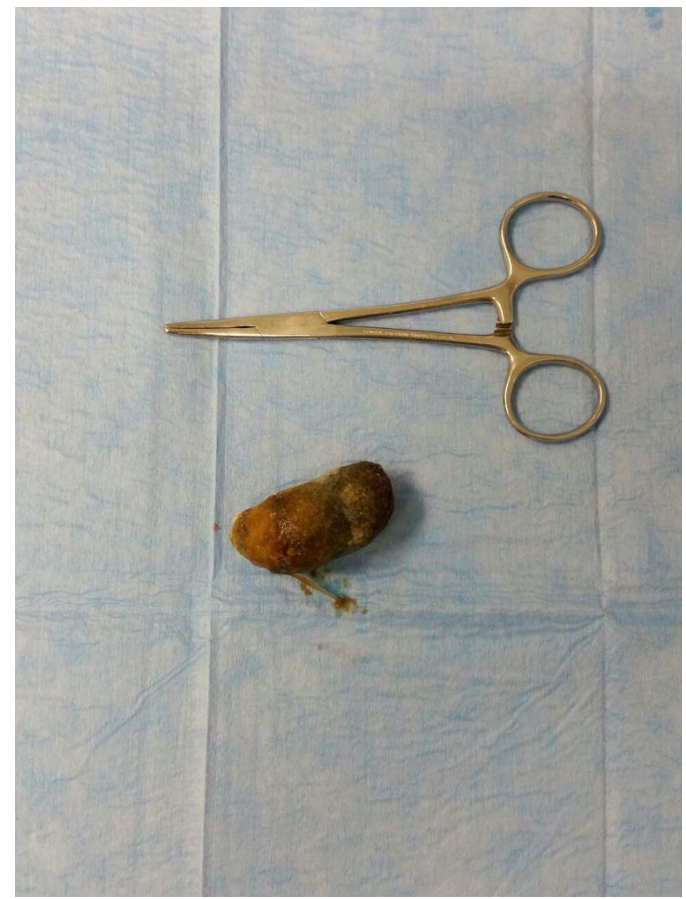

Figure 2 Surgical specimen of the retrieved gallstone.

\section{Learning points}

- Characteristic radiological appearance of gallstone ileus are as described in Rigler's triad.

- Early diagnosis is key and the gold standard imaging modality is an abdominal CT scan.

- Gallstone ileus should be suspected in patients with a history of previous symptomatic cholelithiasis who present with an acute abdomen.

Competing interests None declared.

Patient consent Obtained.

Provenance and peer review Not commissioned; externally peer reviewed.

\section{REFERENCES}

1 Chou JW, Hsu CH, Liao KF, et al. Gallstone ileus: report of two cases and review of the literature. World J Gastro 2007;13:1295-8

2 Zuber-Jerger I, Kullman F, Schneidewind A, et al. Diagnosis and treatment of a patient with gallstone ileus. Nat Rev Gastroenterol Hepatol 2005;2:331-5. 
Copyright 2015 BMJ Publishing Group. All rights reserved. For permission to reuse any of this content visit http://group.bmj.com/group/rights-licensing/permissions.

BMJ Case Report Fellows may re-use this article for personal use and teaching without any further permission.

Become a Fellow of BMJ Case Reports today and you can:

- Submit as many cases as you like

- Enjoy fast sympathetic peer review and rapid publication of accepted articles

- Access all the published articles

- Re-use any of the published material for personal use and teaching without further permission

For information on Institutional Fellowships contact consortiasales@bmjgroup.com

Visit casereports.bmj.com for more articles like this and to become a Fellow 